\begin{tabular}{ll}
\hline Journal of National Institute of Neurosciences Bangladesh, & ISSN (Online) $2518-6612$ \\
July 2019, Vol. 5, No. 2, pp. 127-136 & ISSN (Print) $2410-8030$
\end{tabular}

\title{
Transport of Methylmercury through the Epithelial Type Amino Acid Transporter System B $\mathbf{B}^{0}$
}

\author{
Rafiqul Islam¹, Naohiko Anzai², Nesar Ahmed ${ }^{3}$, Mohammad Ahtashamul Haque ${ }^{4}$, \\ Shamima Ferdous 5 , Sagir Ahmed ${ }^{6}$, MS Jahirul Haque Chowdhury ${ }^{7}$, \\ Md. Tauhidul Islam Chowdhury ${ }^{8}$, Wahida Begum ${ }^{9}$, Mohammad Akter Hossain ${ }^{10}$,
} Farhana Moslehuddin ${ }^{11}$, KM Nazmul Islam Joy ${ }^{12}$, Yoshikatsu Kanai ${ }^{13}$, Hitoshi Endou ${ }^{14}$

\begin{abstract}
${ }^{1}$ Assistant Professor, Department of Pharmacology, National Institute of Neurosciences \& Hospital, Dhaka, Bangladesh; ${ }^{2}$ Professor, Department of Pharmacology, Kyorin University School of Medicine, Tokyo, Japan; ${ }^{3}$ Medical Officer, Department of Medicine, MAG Osmani Medical College, Sylhet, Bangladesh; ${ }^{4}$ Assistant Professor, Department of Oral and Maxillo-Facial Surgery, Dhaka Medical College, Dhaka, Bangladesh; ${ }^{5} \mathrm{PhD}$ in Agriculture, Bangladesh Agriculture University, Mymensingh , Bangladesh; ${ }^{6}$ Consultant (Medicine), Department of Neurology, National Institute of Neurosciences \& Hospital, Dhaka, Bangladesh; ${ }^{7}$ Professor, Department of Clinical Neurology, National Institute of Neurosciences \& Hospital, Dhaka, Bangladesh; ${ }^{8}$ Associate Professor, Department of Neurology, National Institute of Neurosciences \& Hospital, Dhaka, Bangladesh; ${ }^{9}$ Associate Professor, Department of Neuroradiology \& Imaging, National Institute of Neurosciences \& Hospital, Dhaka, Bangladesh; ${ }^{10}$ Assistant professor, Department of Neurology, National Institute of Neurosciences \& Hospital, Dhaka, Bangladesh; ${ }^{11}$ Consultant Physician, Stroke \& Neurology, East Sussex NHS, UK, ${ }^{12}$ Junior Consultan, Medicine, Sarkari Kormochari Hospital, Dhaka, Bangladesh; ${ }^{13}$ Professor, Department of Pharmacology, Kyorin University School of Medicine, Tokyo, Japan; ${ }^{14}$ Professor, Department of Pharmacology, Kyorin University School of Medicine, Tokyo, Japan
\end{abstract}

[Received: 10 April 2019 Accepted: 12 May 2019; Published: 1 July 2019]

\begin{abstract}
Background: System $\mathrm{B}^{0}$ is a sodium dependent transporter that transports wide variety of neutral amino acids in the intestinal and renal proximal tubular epithelial cells. Methylmercury (MeHg) readily and non-enzymatically reacts with cysteine to form conjugate structurally similar to the amino acid methionine. Objective: In this study, we investigated the molecular mechanism of absorptive transport of $\mathrm{MeHg}$ in intestine using Xenopus oocytes expressing hB $\mathrm{B}^{0} \mathrm{AT} 1$ and the uptake of metylmercry-Cys (MeHg-Cys) by heterodimeric amino acids transporter. Methodology: We confirmed the uptake of $\left[{ }^{14} \mathrm{C}\right]$ L-Leucine a potent substrate for the $\mathrm{hB}^{0} \mathrm{AT} 1$ amino acids transporter. The uptake of $\left[{ }^{14} \mathrm{C}\right]$ L-leucine by hB ${ }^{0} \mathrm{AT} 1$ was inhibited by MeHg-Cys conjugate, leucine, cysteine, methinine and phenylalanine in concentration-dependent manner. The $\mathrm{IC}_{50}$ of MeHg-Cys conjugate was significantly lower than that of leucine, cysteine, methinine and phenylalanine, indicating that $\mathrm{hB}^{0} \mathrm{AT} 1$ is a high affinity $\mathrm{MeHg}$ transporter. To assess MeHg-Cys conjugate transport, we measured $\left[{ }^{14} \mathrm{C}\right] \mathrm{MeHg}$ uptake in Xenopus oocytes expressing $\mathrm{hB}^{0} \mathrm{AT} 1$ in presence or absence of sodium. The $\left[{ }^{14} \mathrm{C}\right] \mathrm{MeHg}$ was transport only in the presence of cysteine and the transport was significantly sodium dependent and inhibited by a system $\mathrm{B}^{0}$ inhibitor 2-aminobicyclo-[2,21]- haptane-2-carboxylic acid $(\mathrm{BCH})$. Result: The current findings indicate that $\mathrm{hB}^{0} \mathrm{AT} 1$ and heterodimeric amino acids absorb MeHg in the form of cysteine conjugate from the intestinal lumen across the brush-border membrane in to the cells and is supposed to be plays a critical role in the pathogenesis of Minamata disease and present results descried a major molecular mechanism by which $\mathrm{MeHg}$ is transported across cell membranes and indicate that metal complexes may form a novel class of substrates for amino acid carriers. Conclusion: In this experiment the results also suggest that uptake of Methionine and $\mathrm{MeHg}-\mathrm{Cys}$ by heterodimeric amino acid transporter is significantly correlated where the uptake of Methionine and MeHg-Cys between heterodimeric amino acid transporter and $\mathrm{hB}^{0} \mathrm{AT} 1$ is not correlated. [Journal of National Institute of Neurosciences Bangladesh, 2019;5(2): 127-136]
\end{abstract}

Keywords: Amino acids transport; Methionine; Methyl-mercury-Cysteine conjugate

Correspondence: Dr. Rafiqul Islam, Assistant Professor, Pharmacology, National Institute of Neurosciences \& Hospital, Dhaka, Bangladesh; Email: dr.rafiqulnins123@gmail.com; Cell no.: +8801779306244 / 01924146535

Conflict of interest: There is no conflict of interest relevant to this paper to disclose.

Funding agency: This research project was not funded by any group or any institution.

Contribution to authors: Islam R, Anzai N, Ahmed N, Haque MA, Ferdous S contributed from the protocol preparation, data collection up to report writing. Manuscript writing was performed by Ahmed S, Chowdhury MSJH, Chowdhury MTI, Begum W, Hossain MA, Moslehuddin F, Joy KMNI, Kanai Y, Endou H. Islam R performed the statistical analysis. Islam R has revised the manuscript.

How to cite this article: Islam R, Anzai N, Ahmed N, Haque MA, Ferdous S, Ahmed S, Chowdhury MSJH, Chowdhury MTI, Begum W, Hossain MA, Moslehuddin F, Joy KMNI, Kanai Y, Endou H. Transport of Methylmercury through the Epithelial Type Amino Acid Transporter System B0. J Natl Inst Neurosci Bangladesh, 2019;5(2): 127-136

Copyright: ( 2019 . Islam et al. Published by Journal of National Institute of Neurosciences Bangladesh. This article is published under the Creative Commons CC BY-NC License (https://creativecommons.org/licenses/by-nc/4.0/). This license permits use, distribution and reproduction in any medium, provided the original work is properly cited, and is not used for commercial purposes. 


\section{Introduction}

Methylmercury (MeHg) is a powerful neurotoxicant in all animals, including humans $\mathrm{s}^{1-4}$. The developing brain is particularly sensitive to the effects of $\mathrm{MeHg}$ that can exist in the environment in several forms: elemental, inorganic $\left(\mathrm{Hg}_{2}+\right)$ and/or organic [mainly as methylmercury $\left.\left(\mathrm{CH}_{3} \mathrm{Hg}^{+}\right)\right]$. $\mathrm{CH}_{3} \mathrm{Hg}^{+}$this is the principal form of mercury to which humans are most often exposed, primarily through the consumption of contaminated water and/or fish. Following ingestion of $\mathrm{CH}_{3} \mathrm{Hg}^{+}$, approximately $90.0 \%$ is absorbed by the gastrointestinal tract ${ }^{5}$. In systemic circulation, each methylmercuric ion forms a strong bond with the reduced sulfur atom of several thiol-containing molecules, such as albumin, Cys, glutathione (GSH), homocysteine (Hcy), and N-acetylcysteine (NAC) ${ }^{6}$. Some of these mercuric conjugates serve as transportable substrates of certain carrier proteins in target organs such as the kidneys, liver, and brain ${ }^{7}$. Because the chemical structures of $\mathrm{CH}_{3} \mathrm{Hg}$-S-Cys and the Hcy S-conjugate of $\mathrm{CH}_{3} \mathrm{Hg}^{+}\left(\mathrm{CH}_{3} \mathrm{Hg}\right.$-S-Hcy) are similar to that of the amino acid methionine, it has been postulated that these two conjugates may act as mimics of methionine to gain access to certain compartments of the body ${ }^{8-9}$. Indeed, several studies have provided indirect evidence for the involvement of molecular mimicry in the transport of $\mathrm{CH}_{3} \mathrm{Hg}$-S-Cys ${ }^{10-13}$. More direct evidence for this theory comes from a recent study in Xenopus laevis oocytes in which $\mathrm{CH}_{3} \mathrm{Hg}$-S-Cys was transported by the $\mathrm{Na}^{+}$-independent amino acid transporter, system $\mathrm{L}^{14}$ and $\mathrm{Na}^{+}$-dependent system $\mathrm{B} 0,+15$.

Epithelial resorption of amino acids across the apical membrane in the kidney and intestine is thought to be carried out by four different transporters ${ }^{16}$. Anionic amino acids are taken up by a $\mathrm{Na}^{+}$-dependent aspartate/glutamate transporter ${ }^{17}$, which has been designated system X-AG. Cationic amino acids are taken by system $\mathrm{b}^{0,+}$; the molecular correlate of this transporter being the heteromeric amino acid transporter $\mathrm{r} A B T / b^{0,+} \mathrm{AT}^{18}$. Most of neutral amino acids are thought to be transported by system $\mathrm{B}^{19-20}$. System $\mathrm{B}^{0}$ has been characterized in jejunal brush border vesicle bovine epithelial cells ${ }^{21-24}$ and Caco-2 cells ${ }^{25}$. These studies suggest that systemB $\mathrm{B}^{0}$ is a $\mathrm{Na}^{+}$dependent, chloride-independent transporter ${ }^{26}$. Hartnup disorder, a autosomal recessive defect result from impaired transport of neutral amino acid across epithelial cells of renal proximal tubules and intestinal mucosa ${ }^{27-28}$. Currently the sodium-dependent amino acid transporter $\mathrm{B}^{0} \mathrm{AT} 1$ was cloned, called SLC6A19 and robust expression was observed at renal proximal tubules and intestinal mucosa.
There finding indicate that SLC6A19 was the primary candidate for the gene causing Hartnup disorder ${ }^{29}$.

Most of the MeHg in tissue is normally complexed with water soluble sulfhydryl-containing molecule, primarily with L-cysteine. Mercuric sulfur bonds form spontaneously under physiological condition and they have high thermodynamic stability although these bonds are kinetically labile $\mathrm{e}^{30-31}$. The widespread tissue distribution of the $\mathrm{MeHg}$ leads to the hypothesis that $\mathrm{MeHg}$ may be a substrate for the transporter. In support of this hypothesis, $\mathrm{hB}^{0} \mathrm{AT} 1$, a neutral amino acid transporter is a good candidate as of its high expression in the luminal membrane of the intestine and renal proximal tubules. In this study, we examined the transport of $\mathrm{MeHg}$ in $\mathrm{hB}^{0} \mathrm{AT} 1$ using Xenopus oocytes expression system.

This study focused exclusively on the $\mathrm{Na}^{+}$- dependent component of the $\mathrm{MeHg}$ transport and showed that $\mathrm{hB}^{0} \mathrm{AT} 1$ is a high affinity transporter for $\mathrm{MeHg}$ and the uptake was inhibited by system $\mathrm{B}^{0}$ inhibitor, $\mathrm{BCH}$. Moreover, $\left[{ }^{14} \mathrm{C}\right]$ L- leucine uptake was inhibited by $\mathrm{MeHg}$-cysteine in a concentration -dependent manner, suggesting that this complex is transported by a neutral amino acid carrier. We also examined the transport rate of MeHg in system L, LAT1 and LAT2, system $y^{+} \mathrm{L}$, $y^{+}$LAT1, hAsc-1, system $b^{0+}$, rBAT/BAT1.The present results showed that $\mathrm{hB}^{0} \mathrm{AT} 1$ transporters can transport metal complex with high catalytic efficiency by $\mathrm{hB}^{0} \mathrm{AT} 1$, indicating that these proteins may provide the route of $\mathrm{MeHg}$ entry into intestine and enter the circulation and may account for the rapid and widespread tissue distribution of $\mathrm{MeHg}$. These observations offer important insight into the molecular mechanisms of $\mathrm{MeHg}$ disposition, toxicity, and potential therapies, as well as, provide new understanding in the mechanism of uptake of MeHg.

\section{Experimental Methods and Materials}

Materials and animals: Methylmercury (п) chloride [methyl $\left.{ }^{14} \mathrm{C}\right]$ purchased from American Radiolabeled Chemical Inc. St Louis, Mo. $\left[{ }^{14} \mathrm{C}\right] \mathrm{L}-\mathrm{Leucine},\left[{ }^{14} \mathrm{C}\right] \mathrm{L}-$ Methionine were purchased from Perkin Elmer Life Science Inc. (Boston, MA), Methylmercury-Cystiene conjugate purchased from U.S.A. BCH, L-Cysteine , L-Methionine, L-Leucine, L-Phenylalanine were purchased from Sigma (St Louis, Mo). Non radio labeled Metylmercury (п) Chloride was purchased from Wako, pure Chemical industries, Ltd. T7 m MASSGE m MACHINE kit (Ambion.) poly adenylation of c RNA using the poly (A) tailing kit (Ambion). Mature Xenopus laevis were purchased from Saitama 
Experimental animal, Saitama, Japan. Animal were maintained under a cons.

Synthesis of cRNA: cRNAs for $\mathrm{hB}^{0} \mathrm{AT} 1$ were obtained by in vitro transcription using the T7 $\mathrm{m}$ MASSGE $\mathrm{m}$ MACHINE kit (Ambion) and poly adenylation of $c$ RNA using the poly(A) tailing kit (Ambion). The cRNA for hLAT1 ${ }^{32}$, hLAT2 ${ }^{33}, \mathrm{y}^{+} \mathrm{LAT}^{34}{ }^{34}$, hAsc- ${ }^{35}$ was obtained as described elsewhere.

Xenopus laevis oocyte expression: Xenopus laevis oocyte expression studies were performed as described elsewhere with minor modification (36-37). Briefly, oocyte were treated with collagenase A $(2 \mathrm{mg} / \mathrm{ml})$ (Roche Molecular Biochemical's, Mannheim Germany) for 30 to $50 \mathrm{~min}$ at room temperature in $\mathrm{ca}^{+}$-free medium $(82.5$ $\mathrm{mM} \mathrm{NaCl}, 2 \mathrm{mM} \mathrm{KCl}, 1 \mathrm{mM} \mathrm{MgCl}_{2}$, and $5 \mathrm{mM}$ HEEPS, $\mathrm{pH}$ 7.5) to remove follicular layer and then maintained in modified Barths solution $(88 \mathrm{mM} \mathrm{NaCl}, 1$ $\mathrm{mM} \mathrm{KCl}, 0.33 \mathrm{mM} \mathrm{Ca}\left(\mathrm{NO}_{3}\right)_{2}, 0.41 \mathrm{mM} \mathrm{CaCl}, 0.82$ $\mathrm{mM} \mathrm{MgSO} 4,2.4 \mathrm{mM} \mathrm{NaHCO}$, and $10 \mathrm{mM}$ HEEPS, $\mathrm{pH}$ 7.5). Oocytes were injected with 50ng of c RNA encoding $\mathrm{hB}^{0} \mathrm{AT} 1$. For coexpression of LAT1 and $4 \mathrm{~F} 2 \mathrm{hc}$, LAT2 and 4F2hc,y+ LAT1 and 4F2hc, hAsc-1 and $4 \mathrm{~F} 2 \mathrm{hc}$ in X. laevis oocytes, defolliculated oocytes were injected with LAT1 cRNA (15ng) and $4 \mathrm{~F} 2 \mathrm{hc}(10 \mathrm{ng})$ to give a molar ratio of $1: 132$. After injection of cRNAs, the oocytes were incubated in modified Barth's solution art $180^{\circ} \mathrm{c}$ with a daily change of culture medium for 3 days. Healthy oocytes with a clean brown animal half and distinct equator line were selected for experiments.

Uptake Measurement: Uptake measurements were performed 3 days after injection of cRNAs of $\mathrm{hB}^{0} \mathrm{AT} 1$ and 2 days for other transporters (hLAT1, hLAT2, $y+$ LAT1, hAsc-1). Groups of six to eight oocytes were washed in the uptake solution and then incubated in $500 \mu \mathrm{l}$ of uptake solution (containing $100 \mathrm{mM} \mathrm{NaCl}_{2}, 2$ $\mathrm{mM} \mathrm{KCl}, 1 \mathrm{mM} \mathrm{CaCl}_{2}, 1 \mathrm{mM} \mathrm{MgCl}_{2}, 10 \mathrm{mM}$ HEEPS, and $5 \mathrm{mM}$ Tris, pH 7.4) or Groups of six to eight oocytes were washed in the uptake solution and then incubated at room temperature in $500 \mu 1$ of uptake solution (100 mM chlorine, $2 \mathrm{mM} \mathrm{KCl}, 1.8 \mathrm{mM} \mathrm{CaCl}_{2}$, $1 \mathrm{mM} \mathrm{MgCl}_{2}, 10 \mathrm{mM}$ HEEPS, and $5 \mathrm{mM}$ Tris, $\mathrm{pH} 7.4$ ) containing either ${ }^{14} \mathrm{C} \mathrm{MeHgCL}$ or ${ }^{14} \mathrm{CMeHg}$-Cys complex- for 30 mins $^{36}$. The oocytes were then washed five times with ice-cold uptake solution. Single oocyte were placed into scintillation vials and lysed by adding of $250 \mu \mathrm{l}$ of $10 \%$ SDS. After lysis, $3 \mathrm{ml}$ of scintillation fluid was added, and the radioactivity was determined by liquid scintillation spectrometry, and the values are expressed in picomoles per oocyte per minute ${ }^{37}$.

Functional Expression in HEK 293 cells: Because of the difficulty in evaluating amino acid transport mediated by hBAT1 in Xenopus oocytes, where endogenous transporters activated by rBAT are expressed abundantly ${ }^{38-39}$, HEK293 cells were used for functional expression of rBAT/hBAT1. HEK 293 cells were obtained from the American Type Culture Collection. The cells were grown in DMEM (life technologies) supplemented with sodium bicarbonate $1.5 \mathrm{~g} /$ litre, non-essential amino acid $0.1 \mathrm{mM}$, sodium pyruvate $1 \mathrm{mM}$, and $10.0 \%$ (vol/vol) FBS in a humidified atmosphere of $5 \% \mathrm{CO}_{2}$ at $37^{\circ} \mathrm{C}$. The cells were grown for 3 days to confluence, trypsinized and centrifuge at $200 \times \mathrm{g}$ rpm for 5 minutes, and resuspended in culture medium. Cells were maintained in the growth medium (DMEM medium supplemented with $10 \%$ fetal bovine serum) at $37^{\circ} \mathrm{C}$ in $5 \% \mathrm{CO}_{2}$. The cells were collected and seeded on 24 -well plates $(1 \times 105$ cells/well) in the fresh growth medium. For transfection, $20 \mu \mathrm{g}$ of plasmids were diluted into $1 \mathrm{ml}$ DMEM without serum and mixed with serum followed by incubating 30 minutes at room temperature. The mixture was applied to HEK293 cells maintained in a tissue culture dish (90 mm diameter) with 70 to $90 \%$ confluences. At 24 hours after transfection, the transfected cells were collected and seeded on a 24-well plate ( $2 \times 105 /$ well) in fresh culture media. The uptake measurements were performed at 48 hours after seeding. After removal of growth medium, the cells were washed twice with regular uptake solution [Dulbecco's modified phosphate buffered saline (PBS) supplemented with $5 \mathrm{mmol} / \mathrm{L}$ glucose] and preincubated for 10 minutes at $37^{\circ} \mathrm{C} 40$. Then the medium was replaced by regular uptake solution containing ${ }^{14} \mathrm{C}$ L-Cystiene. Amino acid uptake was terminated by removing uptake medium followed by washing three times with ice-cold regular uptake solution. Then cells were solubilized with $0.1 \mathrm{~N} \mathrm{NaOH}$, and radioactivity was counted. For the uptake measurements, the regular uptake solution was used unless other-wise indicated.

Inhibition Study: For the inhibition experiments, oocytes expressing $\mathrm{hB}^{0} \mathrm{AT} 1$ were incubated for $1 \mathrm{hr}$ in ND96 solution containing $10 \mu \mathrm{M}\left[{ }^{14} \mathrm{C}\right] \mathrm{L}-$ Leucine in presence or absence of amino acids, amino acids analogue $\mathrm{BCH}$ and $\mathrm{MeHg}$-Cys conjugate at different concentration except for $\mathrm{BCH}(1 \mathrm{mM})$. The inhibitor were directly dissolved in ND96 solution from the stock solutions.

Statistical Analysis: Value are shown as mean \pm S.E.M. $(n=6-8)$. Statistical differences were analyzed by Student's unpaired t test. Correlation coefficient was measured by Spearman's test. 


\section{Results}

hB0AT1 is a $\mathrm{Na}^{+}$- dependent transporter that transports almost all of the neutral amino acids. Among them Leucine is the best substrate. Expression of $\mathrm{hB}^{0} \mathrm{AT} 1$ in Xenopus oocytes resulted in a significant increase of leucine uptake activity compared with control water injected oocytes. After injection the oocytes were incubated for three days and $\left[{ }^{14} \mathrm{C}\right] \mathrm{L}$ - leucine uptake $(10 \mu \mathrm{M})$ was measured in the standard uptake solution. As shown in Fig 1. Xenopus oocytes that express hB 0 AT1 exhibited a high level of $\mathrm{L}-\left[{ }^{14} \mathrm{C}\right]$ leucine uptake compared with water injected control oocytes.

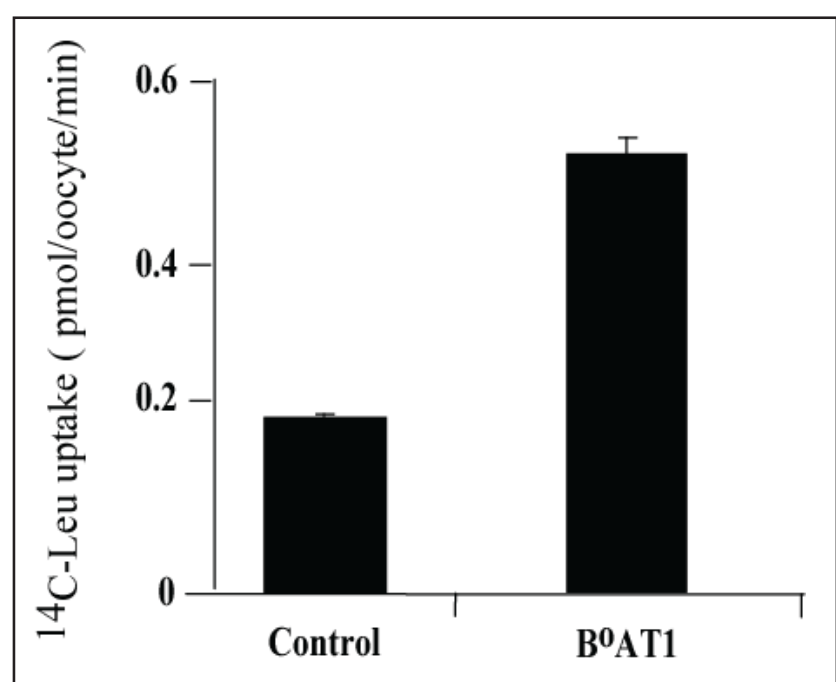

Figure 1: Functional expression of $\mathrm{hB}^{0} \mathrm{AT} 1$. Oocyte were injected with $\mathrm{hB}^{0} \mathrm{AT} 1 \mathrm{cRNA}$ or water injected in the controls. After three days incubation, uptake was performed in standard uptake solution. The uptake rates of [ $\left.{ }^{14} \mathrm{C}\right] \mathrm{L}$-Leucine by control or $\mathrm{hB}^{0} \mathrm{AT} 1$-expressed oocytes were measured for $30 \mathrm{~min}$. Values are mean \pm S.E.M of three independent experiments. The significance difference between control (water injected) and $\mathrm{hB}^{0} \mathrm{AT} 1 \mathrm{cRNA}$-injected oocytes was determined by the unpair $\mathrm{t}$ - test $(\mathrm{p}<.001)$

Xenopus oocytes expressing the hB0AT1 was examined for the uptake of $\left[{ }^{14} \mathrm{C}\right] \mathrm{MeHg}$ and compared with water injected control oocytes. There is no significant difference in the transport of $\mathrm{MeHg}$ between water and hB0AT1 injected oocytes (Figure $2 \mathrm{~A}$ ). When the extracellular $\mathrm{Na}^{+}$was replaced with $\mathrm{Cl}-$ at equimolar concentration, the uptake of $\mathrm{MeHg}$ was not changed compare to control oocytes (Figure 2B), confirming that only the $\left[{ }^{14} \mathrm{C}\right] \mathrm{MeHg}$ cannot uptake by h B0AT1 expressing oocytes.

Methionine is one of high affinity substrate for the system B0AT1 and a molecular homologue of $\mathrm{CH}_{3} \mathrm{Hg}$-S-Cys which is a complex of $\mathrm{MeHg}$ and Cysteine Because of the similar chemical formulae for the MeHg-Cys and methionine (Figure 3A), we examined the methionine transport as confirmation of the functional insertion of $\mathrm{h} \mathrm{B}^{0} \mathrm{AT} 1$ in the plasma membrane of the oocytes. The uptake of methionine was significantly greater in the oocytes injected with cRNA encoding $\mathrm{hB}^{0} \mathrm{AT} 1$ than in the water injected controls (Figure 3B). In blood cystiene is one of the major nonprotein thiols and $\mathrm{MeHg}$ associated with sulfhydryl group of the cys to make a complex of $\mathrm{MeHg}$-Cys. The uptake of MeHg-Cys was examined in hB0AT1 expressing oocytes in presence or absence of $\mathrm{Na}^{+}$in the uptake solution. The transport of MeHg-Cys was significantly higher in $\mathrm{hB}^{0} \mathrm{AT} 1 \mathrm{cRNA}$ injected oocytes than in the controls only in $\mathrm{Na}^{+}$dependent condition (Figure 3C). To facilitate the analysis of the data, the amount of transport activity in water injected control oocytes was subtracted from that in $\mathrm{hB}^{0} \mathrm{AT} 1$ cRNA injected oocytes (Figure 3D).

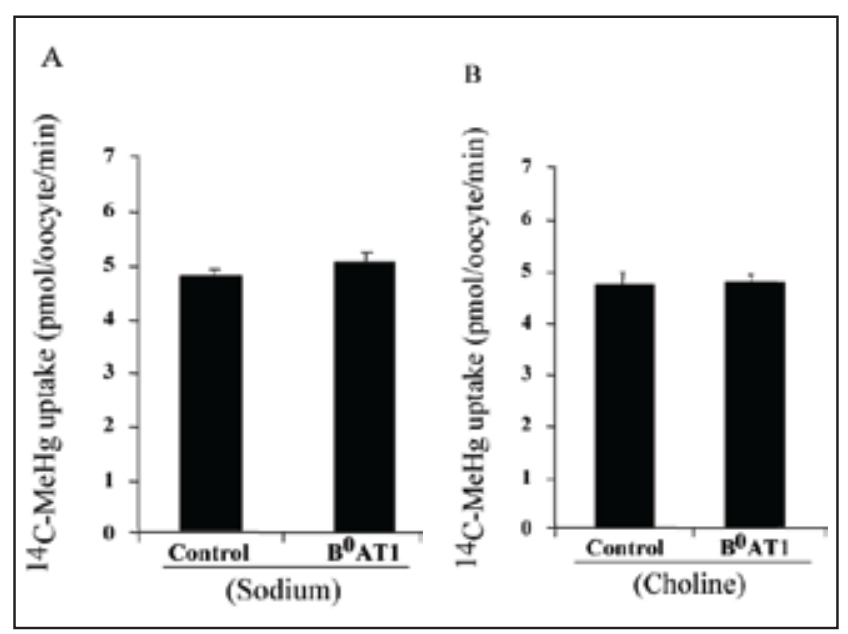

Figure 2: The uptake of $\left[{ }^{14} \mathrm{C}\right] \mathrm{MeHg}$ by $\mathrm{B}^{0} \mathrm{AT} 1$ expressing Xenopus oocytes. The uptake of $\left[{ }^{14} \mathrm{C}\right] \mathrm{MeHg}$ was measured in water injected (control) or $\mathrm{hB}^{0} \mathrm{AT} 1 \mathrm{cRNA}$ injected oocytes. They were incubated with $10 \mu \mathrm{M}\left[{ }^{14} \mathrm{C}\right] \mathrm{MeHg}$ in the presence (A) or absence(B) of extracellular $\mathrm{Na}^{+}$. Extracellular $\mathrm{Na}^{+}$ was replaced with equimolar concentration of choline. The uptake was measured for 30mins at room temperature. Values are mean \pm S.E.M of three independent experiments.

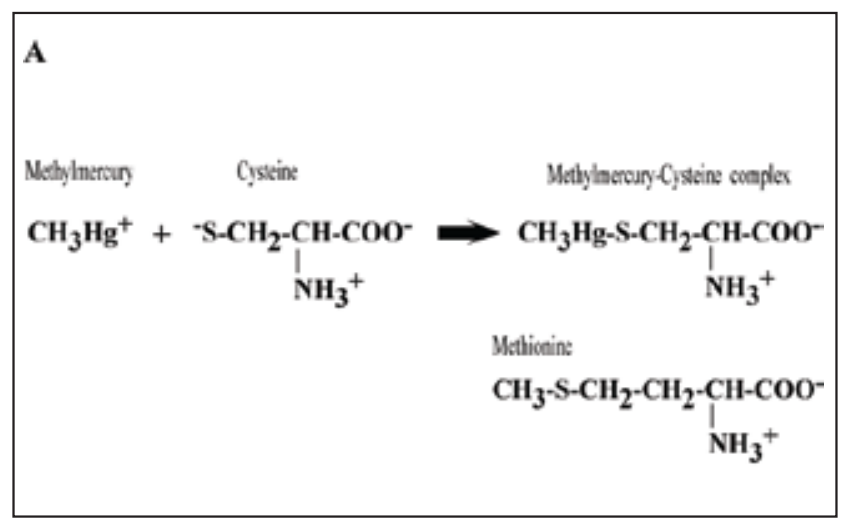




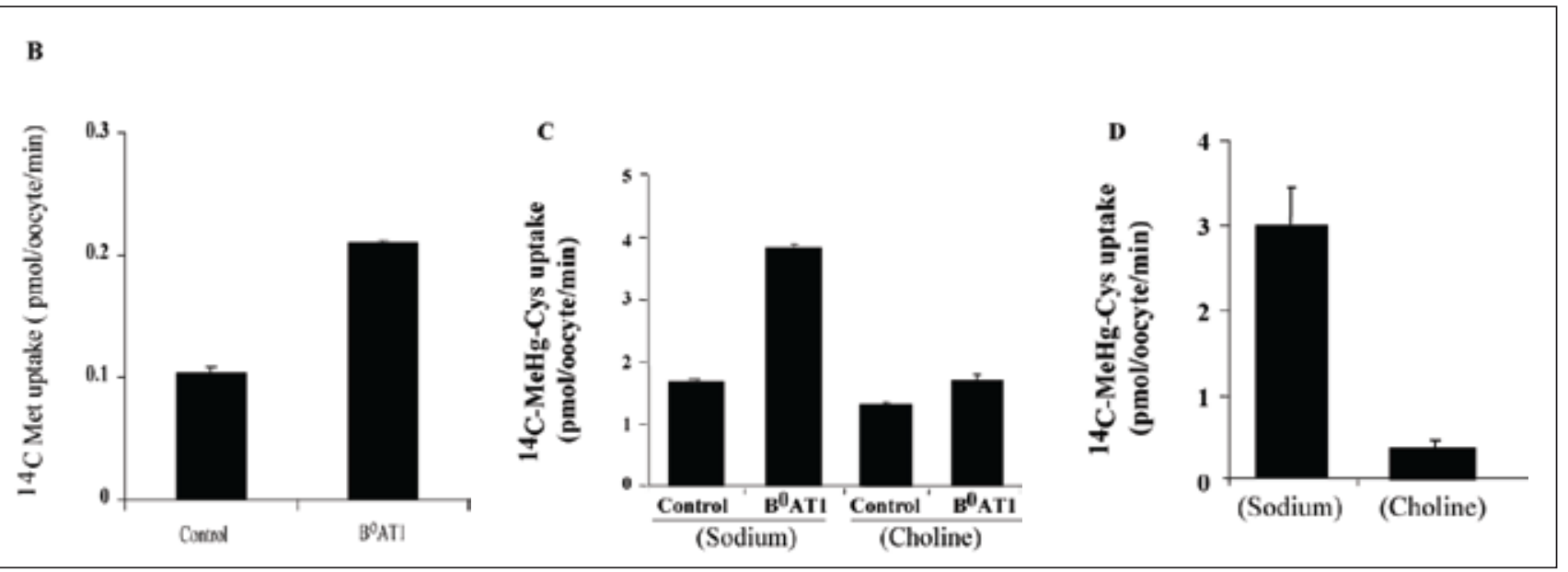

Figure 3: The uptake of $\left[{ }^{14} \mathrm{C}\right]$ Met and $\left[{ }^{14} \mathrm{C}\right] \mathrm{MeHg}-\mathrm{Cys}$ in $\mathrm{h} \mathrm{B}^{0} \mathrm{AT} 1$ expressing oocytes. Chemical formulae of methylmercury-cysteine complex and methionine (A). $\left.{ }^{14} \mathrm{C}\right]$ Methionine $10 \mu \mathrm{M}$ uptake was determined after three days incubation in standard uptake solution (B).Ion dependence uptake of $10 \mu \mathrm{M}\left[{ }^{14} \mathrm{C}\right] \mathrm{MeHg}-\mathrm{Cys}$ via $\mathrm{hB}^{0} \mathrm{AT} 1$ was determined in the presence or absence of extracellular $\mathrm{Na}^{+}$. Extracellular $\mathrm{Na}^{+}$was replaced with equimolar concentration of choline. Each Bar represeants the mean \pm S.E.M of three independent experiments $(\mathrm{C})$. The transport activity of $10 \mu \mathrm{M}\left[{ }^{14} \mathrm{C}\right] \mathrm{MeHg}-\mathrm{Cys}$ in each solution were subtracted(D). The significance difference between control (water injected) and hB ${ }^{0} \mathrm{AT} 1 \mathrm{cRNA}$-injected oocytes was determined by the un pair t- test $(\mathrm{p}<0.001)$.

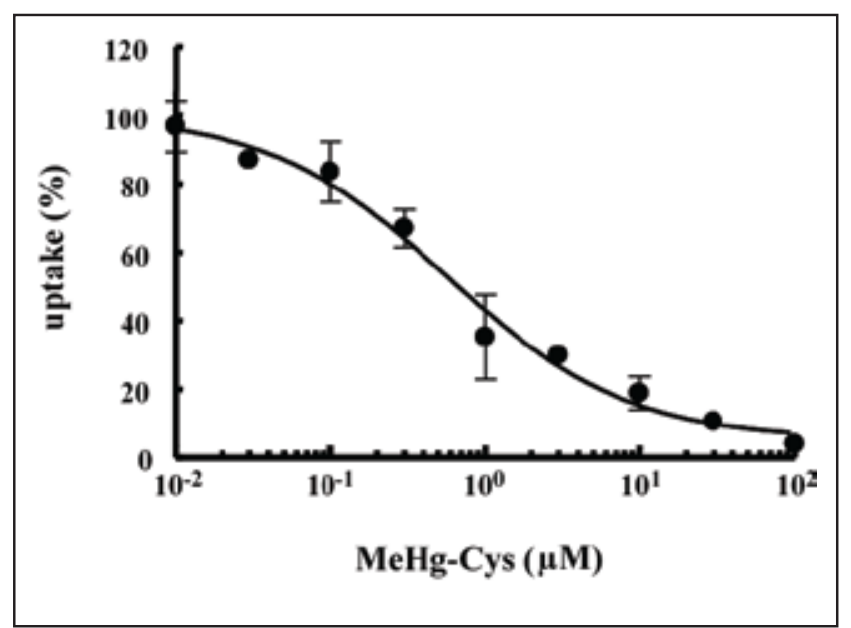

Figure 4. The concentration dependent inhibition of $\left[{ }^{14} \mathrm{C}\right]$ L-Leucine uptake by MeHg-Cys. The $10 \mu \mathrm{M}\left[{ }^{14} \mathrm{C}\right] \mathrm{L}-$ Leucine uptake was measured for 30 min with $\mathrm{Na}^{+}$containing uptake solution in the presence of varied concentrations of MeHg-Cys and expressed as a percentage of control L-Leucine uptake in the absence of MeHg-Cys. Each bar represents the mean \pm S.E.M of three independent experiments

The effect of MeHg-Cys on the L-leucine transport was investigated by measuring the $\left[{ }^{14} \mathrm{C}\right]$ L-Leucine uptake $(10 \mu \mathrm{M})$ in the presence of varied concentration of $\mathrm{MeHg}-\mathrm{Cys}$ in $\mathrm{hB}^{0} \mathrm{AT} 1$ expressing oocytes. As shown in the Figure $4\left[{ }^{14} \mathrm{C}\right]$ L-leucine uptake was inhibited in a concentration-dependent manner with $\mathrm{IC}_{50}$ value of 0.8 $\pm 0.21 \mu \mathrm{M}$ (mean \pm S.E. of three separate experiments). Similarly $\left[{ }^{14} \mathrm{C}\right] \mathrm{L}$-leucine uptake $(10 \mu \mathrm{M})$ was measured in the presence of non-radiolabeled compounds
L-Leucine, L-Phenylalanine, L-Methionine, L-Cysteine at different concentration in the $\mathrm{Na}^{+}$containing uptake solution and $\mathrm{IC}_{50}$ value was calculated (Table 1). The $\mathrm{IC}_{50}$ of $\mathrm{MeHg}$-Cys conjugate was significantly lower than that of Leucine, Cysteine, Methionine and Phenylalanine, indicating that $\mathrm{hB}^{0} \mathrm{AT} 1$ is a high affinity $\mathrm{MeHg}$ transporter.

Table 1. $\mathrm{IC}_{50}$ value of amino acids and $\mathrm{MeHg}-\mathrm{Cys}$ for $\left[{ }^{14} \mathrm{C}\right]$ Leucine uptake mediated by $\mathrm{hB}^{0} \mathrm{AT} 1$ expressing oocyte

\begin{tabular}{lr}
\hline Substrates & $\mathrm{IC}_{50}(\mu \mathrm{M})$ \\
\hline Leucine & $7.5 \pm 0.43$ \\
Phenylalaline & $3.12 \pm 0.57$ \\
Cysteine & $7.5 \pm 0.70$ \\
Methionine & $26.9 \pm 0.84$ \\
MeHg-cys & $0.8 \pm 0.21$
\end{tabular}

$\mathrm{B}^{0} \mathrm{AT} 1$ expressing oocytes were incubated in a solution containnig $10(\mu \mathrm{M})\left[{ }^{14} \mathrm{C}\right]$ Leucine in presence of various concentration of amino acids and $\mathrm{MeHg}$-cys . Each value represents the mean \pm S.E.M of six to eight oocytes from 3 separated experiment.

The effect of amino acid analogue system $\mathrm{B}^{0}$ specific inhibitor BCH (2-aminobicyclo- (2,2,1)-heptane-2carboxylic acid) was observed in $\left[{ }^{14} \mathrm{C}\right] \mathrm{MeHg}-\mathrm{Cys}$ uptake expressing hB0AT1 oocytes ( Figure $5 \mathrm{~A}$ ). $\left[{ }^{14 \mathrm{C}}\right]$ MeHg-Cys uptake $(10 \mu \mathrm{M})$ was measured in presence or absence of $1 \mathrm{mM}$ of $\mathrm{BCH}$ in the $\mathrm{Na}^{+}$containing uptake solution.

The uptake of $\left[{ }^{14} \mathrm{C}\right] \mathrm{MeHg}$-Cys in water injected control oocyte was subtracted from $\mathrm{hB}^{0} \mathrm{AT} 1$ expressing oocytes and shown in Fig. 5B. The significant 
inhibition of $\left[{ }^{14} \mathrm{C}\right] \mathrm{MeHg}$-Cys uptake was observed in presence of $\mathrm{BCH}$.

Heterodimeric amino acid transporters play pivotal role in the transepithelial transport of neutral and basic amino acids at renal proximal tubules and intestinal epithelia. Methionine is a common transportable substrate in these transporters. The uptake of methionine and MeHg-Cys complex, structurally similar compounds was examined in apical and basolateral membrane transporter. The uptake was markedly enhanced in oocytes injecting with cRNA for hB0AT1, LAT1/4F2hc, LAT2/4F2hc, and $\mathrm{y}+\mathrm{LAT} 1 / 4 \mathrm{Fhc}$ but not highly enhanced in oocytes

A

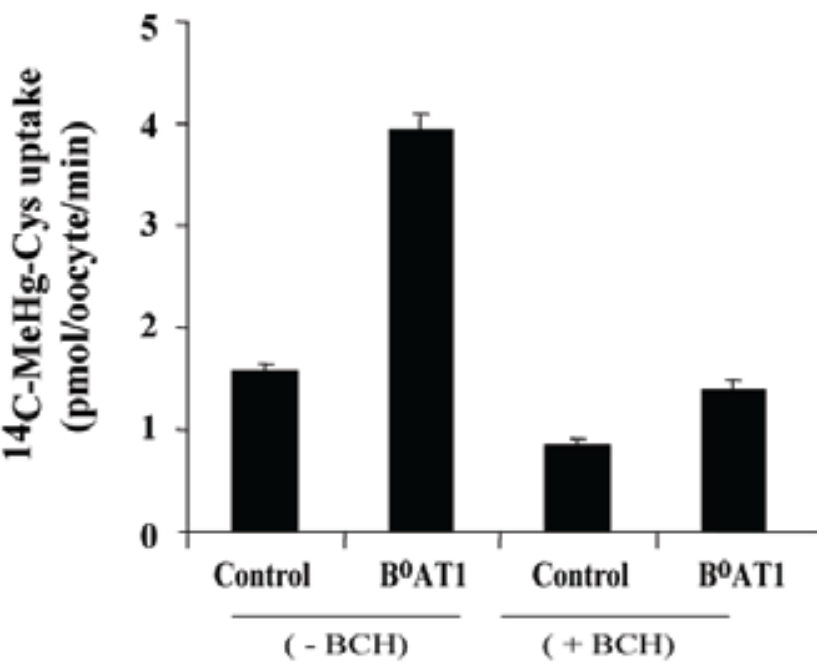

injecting with cRNA for $\mathrm{h}$ Asc-1/4F2hc. However Methionine and $\mathrm{MeHg}$-Cys complex uptake was markedly enhanced in BAT1/rBAT co-transfected in HEK293 cells. MeHg-Cys and methionine uptake is correlated among examined amino acids transporter. As shown in Figure 6A and B the uptake of MeHg-Cys and methionine is directly correlated in heterodimeric amino acids transpoter ( LAT1/ 4F2hc, LAT2/ 4F2hc, $\mathrm{y}+\mathrm{LAT} 1 / 4 \mathrm{~F} 2 \mathrm{hc}, \mathrm{hAsc}-1 / 4 \mathrm{~F} 2 \mathrm{hc}$ and BAT1/r BAT but no positive correlation was observed between the heterodimeric amino acid transporters with hB0AT1 (Figure 6C)

Figure 5: Inhibition of $\left[{ }^{14} \mathrm{C}\right] \mathrm{MeHg}$-Cys uptake by amino acid analog $\mathrm{BCH}$ in oocytes. Control (water injected) and $\mathrm{hB}^{0} \mathrm{AT} 1$ cRNA injected oocytes were incubated for three days and $10 \mu \mathrm{M}\left[{ }^{14} \mathrm{C}\right] \mathrm{MeHg}$-Cys uptake was measured in the absence and presence of $1 \mathrm{mM}$ system $\mathrm{B}^{0}$ specific inhibitor $\mathrm{BCH}(\mathrm{A})$. The transport activity of $10 \mu \mathrm{M}\left[{ }^{14} \mathrm{C}\right] \mathrm{MeHg}$-Cys in control and $\mathrm{hB}^{0} \mathrm{AT} 1$ were subtracted (B).

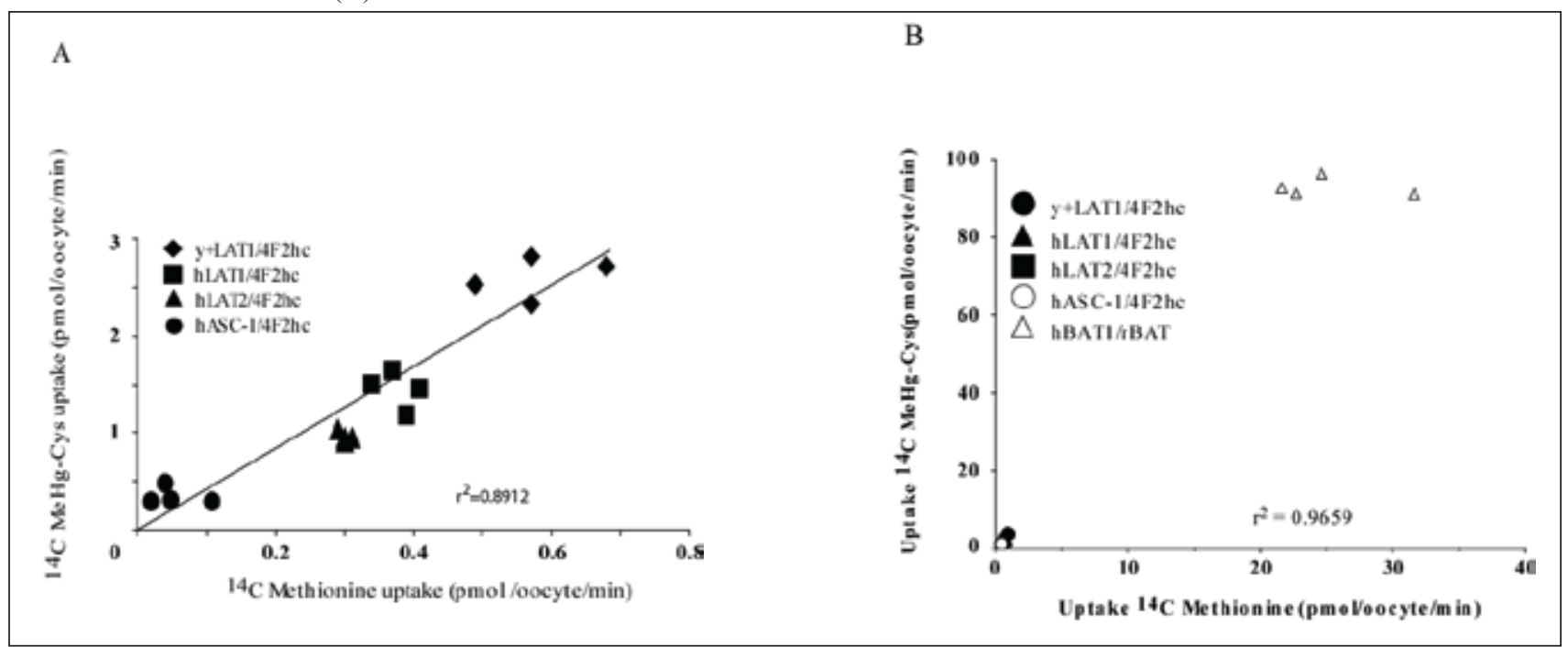




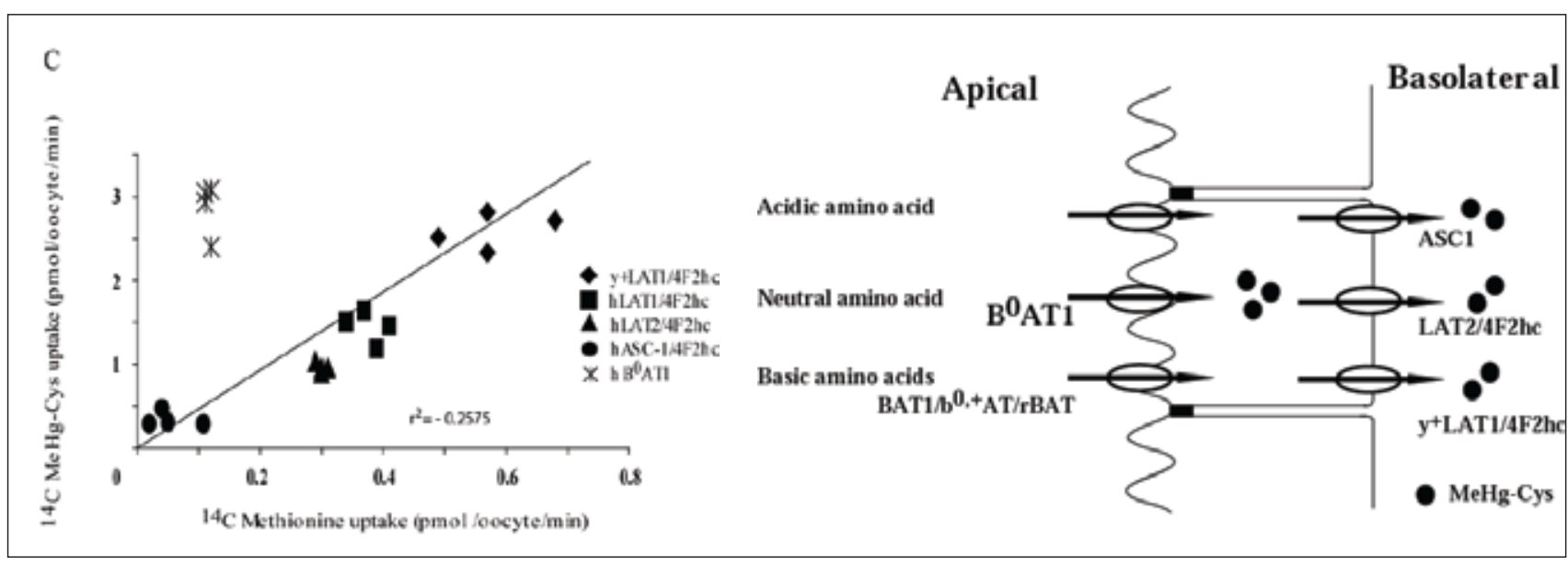

Figure 7: Transepithelial transport of MeHg-Cys in kidney and small intestine. Transporter in apical and basolateral membrane in kidney and small intestine plays a critical role in the absorption of amino acid. MeHg-Cys structurally similar to amino acid methionine are also transported by these transporters

\section{Discussion}

Methylmercury is the most frequently encountered organic mercuric compound in the environment that form mainly as a result of methylation of inorganic form of mercury by microorganisms in soil and water. The mercuric ions have a greater predilection to bond to reduce sulfur atoms, especially thiols containing molecules, such as glutathione, cysteine, homocysteine, $\mathrm{N}$-acetylcysteine, metallothionein, and albumin. During the initial hours after the exposure of inorganic mercury, there is a rapid decrease in the plasma level with a rapid increase in kidney and liver. Mercuric S-conjugates of small endogenous thiols like glutathione and cysteine are primarily the transportable forms in the kidney and liver. The kidney are the primary target organ for inorganic mercury to taken up, accumulated and express toxicity ${ }^{41}$. The molecular mechanisms of methylmercury are not yet completely understood, but several studies showing the importance of amino acid transporter for its pharmacokinetic behaviors.

Cellular requirements of amino acid are accomplished by several families of amino acid transporter that expressed differentially and can accept a variety of structurally related amino acids or amino acid analogues as substrate. Amino acid transporter distributed in the apical and basolateral membrane of the renal proximal tubules and small intestine are in concert to play a critical role in the distribution of amino acids in a sodium-dependent and sodium-independent manner. System $\mathrm{b}^{0},+, \mathrm{B}^{0}, \mathrm{X}-\mathrm{AG}$ are located in apical membrane whereas system $\mathrm{L}$ and $\mathrm{y}^{+} \mathrm{L}$ are heterodimeric amino acid transporters in the basolateral membrane.
Numerous sets of recent findings both in vivo and in vitro indicate that mercuric conjugates of cysteine are the primary species of inorganic mercury transported at the luminal membrane of proximal tubular cells. Methylmercury-cysteine conjugate have been implicated as potential mimics of methionine and methionine is a major substrate for the amino acid transporters. This study provides one of the direct evidence using the $\mathrm{hB}^{0} \mathrm{AT} 1$ that amino acid transporter are involve in metal transport. Moreover, our result provides additional evidence that $\mathrm{hB}^{0} \mathrm{AT} 1$ is the high affinity methylmercury-cysteine transporter among the transporters studied. In this study, we use the Xenopus oocyte system injected with cRNA of $\mathrm{hB}^{0} \mathrm{AT} 1$. To confirm the $\mathrm{hB}^{0} \mathrm{AT} 1$ expression in the current oocyte model, we measured the uptake of amino acid leucine in water and $\mathrm{hB}^{0} \mathrm{AT} 1$ injected oocytes. The transport of leucine was significantly greater in the $\mathrm{hB}^{0} \mathrm{AT} 1 \mathrm{cRNA}$ injected oocytes than in control, reflecting the presence of a functional $\mathrm{hB}^{0} \mathrm{AT} 1$. Methionine and methylmercury-cysteine are equally the good substrate for this transporter, indeed transport rate were higher for methylmercury-cysteine, whereas methylmercury itself was not a transportable substrate for $\mathrm{hB}^{0} \mathrm{AT} 1$. It is possible that some of the measured uptake mediated by the endogenous amino acid transporter other than $\mathrm{hB}^{0} \mathrm{AT} 1$. We subtracted the water injected uptake from the uptake by $\mathrm{hB}^{0} \mathrm{AT} 1$-injected oocytes; it became obvious that a large fraction of the uptake was mediated by the amino acid transporter $\mathrm{hB}^{0} \mathrm{AT} 1$.

Concentration dependent inhibition of methylmercurycysteine, L-Leucine, L-Phenylalanine, L-Methionine, L-Cysteine on the uptake of $\left[{ }^{14} \mathrm{C}\right] \mathrm{L}$-leucine provides additional support in the context of IC50 value where 
Methylmercury-Cysteine showed the lowest even than the leucine which is a good substrate for the system $\mathrm{B}^{0}$. Inhibition of Methylmercury-Cysteine uptake by the amino acid analogue $\mathrm{BCH}$ provides further evidence of Methylmercury-Cysteine transported by the amino acid carrier. These findings demonstrate that the uptake of Methylmercury-Cysteine complex is a saturable and inhibited by large neutral amino acid and amino acid analogue $\mathrm{BCH}$. Interestingly, in water injected oocytes, the uptake of Methylmercury-Cysteine was inhibited by $\mathrm{BCH}$. This reduction is most likely due to the inhibition of the endogenous amino acid transporters and the presence of these transporters does not alter the significance of the current findings.

Various amino acid transport systems contribute to the trans epithelial transport of amino acid at the renal proximal tubules and intestinal epithelial cells. Acidic amino acids are absorbed from the luminal fluid via the sodium dependent system X-AG glutamate transporter EAAC1, neutral amino acid via the system $\mathrm{B}^{0}, \mathrm{~B}^{0} \mathrm{AT} 1$ and cystine and basic amino acid absorbed via the system $b^{0,+}, \mathrm{rBAT} / \mathrm{BAT} 1$. All of these transporters are located at the apical membrane. The heterodimeric amino acid transporters system L, LAT1 and LAT2, system $\mathrm{y}^{+} \mathrm{L}, \mathrm{y}^{+} \mathrm{LAT} 1$, system Asc, hAsc-1 at the basolateral plasma membrane plays a important role for the exit path ${ }^{42}$. In this study, we examined the methionine and methylmercury-cysteine uptake with all of these transporters. The basolateral heterodimeric amino acid transporter shows a positive correlation in the uptake of methionine and methylmercury-cysteine, indeed, negative correlation was observed when the uptake of $\mathrm{hB}^{0} \mathrm{AT} 1$ added. The positive correlation among the heterodimeric amino acid transporter showed a similar affinity for the uptake of methionine and methylmercury-cysteine whereas $\mathrm{B}^{0} \mathrm{AT} 1$ has the higher affinity for the methylmercury-cysteine than the methionine indicating a big difference in the pharmacokinetics of methylmercury. It is important to note that the implications for this finding may spread beyond the scope of system $\mathrm{B}^{0}$.

Methylmercury secreted from liver cells into bile as the glutathione complex is converted to cysteine complex which is promptly reabsorbed in the small intestine. Intestinal absorption of methylmercury complexes was studied by means of direct injection of mercury compounds into ligated intestinal segments of rats, showing that Methylmercury-Cys play important roles in the intestinal reabsorption of methylmercury during its enterohepatic circulation ${ }^{43}$. Methylmercury uptake requiring metabolic energy and could be inhibited by probenecid and ouabain ${ }^{44}$. Studied in the everted sac of rat small intestine showed that with an increase in $\mathrm{pH}$ the transport of $\mathrm{HgCl}_{2}$ through the tissue increased. Similar $\mathrm{pH}$ dependence was observed in the uptake of $\mathrm{HgO}^{45}$. All of these studies suggested a neutral amino acid carrier mechanism may exist for the absorption of the methylmercury in the intestine. In the intestine a gradient of the expression of the $\mathrm{hB}^{0} \mathrm{AT} 1$ was observed toward the tip of the villi and the function of which showed strong $\mathrm{pH}$ dependency. The localization of this transporter with highest affinity for the methylmercury complex can explain the mechanism of absorption of the complex.

The concentration of the free cysteine in plasma is in the range of 5-20 $\mu \mathrm{M}$. Plasma glutathione has a rapid turnover giving the cysteine available for the conjugation with methylmercury. Methionine is a transportable substrate for many amino acid carriers, like system $\mathrm{L}, \mathrm{b}^{0,+}, \mathrm{y}^{+} \mathrm{L}$ and $\mathrm{A}$. Multi organ distribution of these transporters serve a mechanism for the entry of methylmercury-cysteine complex and contribute to the detrimental effects observed following exposure of methylmercury. The highest affinity for the methylmercury-cysteine complex and localization of $\mathrm{hB}^{0} \mathrm{AT} 1$ in the intestinal villi and renal proximal tubular cells added a mechanism in the transport of this toxic metal. Current therapy for $\mathrm{MeHg}$ poisoning relies on chelators to enhance the elimination into urine or faeces. Addition of the inhibitor for the neutral amino acid carrier $\mathrm{hB}^{0} \mathrm{AT} 1$ may be more effective in limiting tissue uptake.

\section{Conclusion}

In this experiment the results also suggest that uptake of Methionine and MeHg-Cys by heterodimeric amino acid transporter is significantly correlated where the uptake of Methionine and MeHg-Cys between heterodimeric amino acid transporter and $\mathrm{hB}^{0} \mathrm{AT} 1$ is not correlated. Reabsorption of amino acids in kidney and intestine is mediated by transporters, which refer groups of amino acids with similar physio-chemical properties.

\section{References}

1. Clarkson TW. The pharmacology of mercury compounds. Annu. Rev. Pharmacol.1072; 12:375-406

2. Clarkson TW. The three modern faces of mercury. Environ. Health Perspect 2002;110 (Suppl. 1):11-23

3. World Health Organization (WHO) Mercury Environ. Health Criter 1990;101:1-144

4. Clarkson TW, Cox C, Davidson PW, Myers GJ. Mercury in fish. Science (Washington, D.C.) 1998;279:459-461

5. Kershaw TG, Clarkson TW, Dhahir P. The relation between 
blood levels and dose of methyl mercury in man. Arch Environ Health 1980;35: 28-36

6. Fuhr B, Rabenstein DL. Nuclear magnetic resonance studies of the solution chemistry of metal complexes: IX. The binding of cadmium, zinc, lead, and mercury by glutathione. J Am Chem Soc 1973;95:6944-6950

7. Bridges CC, Zalups RK. Molecular and ionic mimicry and the transport of toxic metals. Toxicol Appl Pharmacol 2005;204:274-308

8. Clarkson TW. Molecular and ionic mimicry of toxic metals. Annu Rev Pharmacol Toxicol 1993;32:545-571

9. Bridges, C.C., and Zalups, R.K.: Cystine and glutamate transport in renal epithelial cells transfected with human system Xc . Kidney Int 2005;68:653-664

10 Aschner M. Brain, kidney, and liver 203Hg-methyl mercury uptake in the rat: relationship to the neutral amino acid carrier. Pharmacol Toxicol 1989;65:17-20

11. Aschner M, Clarkson W. Methyl mercury uptake across bovine brain capillary endothelial cells in vitro: the role of amino acids. Pharmacol Toxicol 1989;64:293-299

12. Kerper L, Ballatori N, Clarkson TW. Methylmercury transport across the blood-brain barrier by an amino acid carrier. Am J Physiol 1992;262:761-765

13. Mokrzan EM, Kerper LE, Ballatori N, Clarkson TW. Methylmercury-thiol uptake into cultured brain capillary endothelial cells on amino acid system L. J Pharmacol Exp Ther $1995 ; 272: 1277-1284$

14. Tracey A, Simmons-Willis S, Albert $\mathrm{KOH}$, Clarkson TW, Ballatori N. Transport of neurotoxicant by molecular mimicry: the methylmercury-L-cysteine is a substrate for human L-type large neutral amino acid transporter ( LAT) 1 and LAT2 Biochem J 2002;367: 239-246

15. Christy,C.Bridges and Rudolfs, K. Zalups.: System B0+ and the transport of thiol-S-Conjugates of Methylmercury JPET 2006;319 (2): 948-956

16. Palacin M, Estevez R, Bertran J, Zorzano A. Molecular biology of mammalian plasma membrane amino acid transporters. Physiol Rev. 1998;78: 969-1054

17. Kanai Y, Stelzner M, Nussberger S, Khawaja S, Hebert SC, Smith CP, Hediger MA. The neuronal and epithelial human high affinity glutamate transporter. Insight into the structure and mechanism of transport. J Biol Chem 1994;269: 20599-20606

18. Palacin M, Borsani G, Sebastio G. The molecular bases of cystinuria and lysinuric protein intolerance. Curr Opin Genet Dev 2001;11:328-335

19. Broer S. Apaptation of plasma membrane amino acid transport mechanisms to physiological demands. Pfluegers Arch Eur J Physiol 2002; 444: 457-466

20. Chillaron J, Estevez R, Mora C, Wagner CA, Suessbrich H, Lang F, Gelpi JL, Testar X, Busch AE, Zorzano A, Palacin M. Obligatory amino acid exchange via systems b0,+- like and $\mathrm{y}^{+-}$ like. A tertiary active transport mechanism for renal reabsorption of cystine and dibasic amino acids. J Biol Chem 1996; 271: $17761-17770$

21. Stevens, B. R., Ross, H. J., and Wright, E. M.: Multiple transport pathways for neutral amino acids in rabbit jejunal brush border vesicles. J Membr Biol 1982;66: 213-225

22. Maenz DD, Patience JF. L-threonine transport in pig jejunal brush border membrane vesicles. Functional characterization of the unique system B in the intestinal epithelium. J Biol Chem 1992;267: 22079-22086

23. Munck BG, Munck LK. Phynylalanine transport in rabbit small intestine. J Physiol 1994; 480: 99-107

24. Doyle FA, McGivan JD. Reconstitution and identification of major $\mathrm{Na}(+)$ - dependent neutral amino acid-transport proteion from bovine renal brush-border membrane vesicle. Biochim. Biophys. Acta 1992;1104: 55-62

25. Souba WW, Pan M, Stevens BR. Kinetics of the sodium-dependent glutamine transporter in human intestinal cell confluet monolayers. Biochem Biophys Res Commun 1992;188: 746-753 26. Palacin M, Bertran J, Zorzano A. Heteromeric amino acid transporters explain inherited aminoacidurias. Curr Opin Nephrol. Hypertens. 2000

27. Levy LL. The Metabolic and Molecular Bases of Inherited Diseases (Scriver, C. R., Beaudet, A L, Sly, W S, Valle, D, ed) . 3: 4957-4969(2001). McGraw-Hill Inc., New York

28. Baron DN, Dent CE, Harris H, Hart EW, Jepson JB. Herediatry pellagra-like skin rash with temporary cerebellar ataxia, constant renal amino-aciduria, and other bizarre biochemical features. Lancet 1956;2: 421-428

29. Kleta R, Romeo E, Ristic Z, Ohura T, Stuart C, Arcos-Burgos M, et al. Mutations in SLC6A19 (hB0AT1) are Associated with the Hartnup disorder. Nature Genet. 2004

30. Carty AJ, Malone SJ. The chemistry of mercury in biological systems. In The Biogeochemistry of Mercury in the Environment,

Elsevier/North-Holland Biomedical Press, Amsterdam 3: (Nriagu, J. O., ed. 433-479;1979

31. Hughes WL. A physicochemical rationale for the biological activity of mercury and its compounds. Ann. N.Y. Acad. Sci. 1957;65: 454-460

32. Kanai Y, Segawa H, Miyamoto K, Uchino H, Takeda E, Endou $\mathrm{H}$. Expression cloning and characterization of a transporeter for large neutral Amino acids activated by the heavy chain of 4F2ho antigen ( CD98). J Biol Chem 1998;273 (37): 23629-23632

33. Segawa H, Fukasawa Y, Miyamoto K, Takeda E, Endou H, Kanai Y. Identification and functional characterization of a $\mathrm{Na}+-$ independent neutral amino acid transporter with broad substrate selectivity. J Biol Chem 1999;274(28): 19745-19751

34. Kanai Y, Fukasawa Y, Cha HS, Segawa H, Chairoungdua A, $\mathrm{Kim} \mathrm{KD}$, et al. Transport properties of a system $\mathrm{y}+\mathrm{L}$ neutral and basic amino acid transporter. J Biol Chem 2000;275(27):20787-20793

35. Fukasawa Y, Segawa H, Kim YJ, Chairoungdua A, Kim KD, Matsuo H, Cha HS, Endou H, Kanai Y. Identification and characterization of a $\mathrm{Na}+-$ Neutral amino acid transporter that associates with the 4F2 heavy chain and exhibit substrate selectivity for small neutral D- and L-amino acids. J.Biol.Chem 2000;275(13): 9690-9698

36. Kanai, Y., Hediger, M.A.: Primary structure and functional characterization of high affinity glutamate transporter. Nature 1992;360: 467-471

37. Utsunomiya-Tate, N., Endou, H., Kanai, Y. Cloning and functional characterization of a system Asc-like $\mathrm{Na}+$-dependent neutral amino acid transporter. J. Biol. Chem. 1996;271:14883-14890

38. Weels, R.G., Hediger, M.A. Cloning of rat kidney c DNA that stimulates dibasic and neutral amino acid transport and has sequence similarity to glucosidases. Proc Natl acad sci USA 1992;89: 5596-5600

39. Bertran , J., Wernerw, A., Moore, M.L. et al. Expression cloning of a c DNA from rabbit kidney cortex that induces a single transport system for cystine and dibasic and neutral amino acids. Proc Natl acad sci USA 1992;89: 5601-5605

40. Chairoungdua, A., Segawa, H., Kim, J.Y., Miyamoto, K., Haga, H., Fukui, Y., Mizoguchi, K., Ito, H., Takeda, E., Endou, H., and Kanai, Y. Identification of an amino acid transporter associated with cystinuria-related type $\Pi$ membrane glycoprotein. J Biol Chem 1999;274: 28845-28848 
41. Rudolfs, K., Zalups. Molecular interactions with mercury in the kidney.Pharmacological reviews 2000;52(1):113-43

42. Kanai, Y. and Endou, H. : Heterodimeric amino acid transporters: molecular biology and pathological and pharmacological relevance Current Drug Metabolism 2001;2 (4): 339-354

43. Urano, I. Iwasaki, A. Himeno S,Naganuma, A.Imura, N.: Absorption of methylmercury compounds from rat intestine.Toxicol lett 1990;50 (2-3): 159-64
44. Leaner, JJ. Mason, RP.: Methylmercury accumulation and fluxes across the intestine of channel catfish, Tctalurus punctatus Comp Biochem Physiol C Toxical Pharmacol 2002;132(2): 247-59

45. Endo,T. Nakaya, S. Kimura, R. Murata, T. : Gastrointestinal absorption of inorganic mercuric compounds in vitro. Toxicol appl pharmacol 1986;83(2): 187-96 